Nuntius Antiquus, Belo Horizonte, v. 13, n. 2, p. 39-57, 2017

\title{
Religious Paradox and Aporia ${ }^{1}$
}

\section{Paradoxo religioso e aporia}

\author{
Ioannis Petropoulos \\ Classics Department of Greek Philology \\ Democritus University of Thrace, Thrace / Greece \\ Center for Hellenic Studies-Harvard University, Nafplio / Greece \\ yiannis@chs.harvard.edu
}

\begin{abstract}
Focusing on religious or metaphysical paradox, which is, strangely, a neglected subject, this paper surveys well-known and little known instances in ancient Greek literature and early Christian sources. Religious paradox is highlighted in texts ranging from Hesiod, Archilochus, Heraclitus, and Euripides' Bacchae to the Gospel of St John, St Paul, and the $6^{\text {th }}$ century Akathistos Hymnos in honour of the Virgin Mary. Aporia in the wake of religious paradox confirms human limitation and points to the transcendence of the divine. Christianity, the religion of paradox par excellence, acknowledges the impossibility of offering philosophical "solutions" to the paradoxes and aporiai of dogma, and resorts to oxymoron and paradox as the only adequate form of expression. The only recourse before the estranging dislocation of order and logic

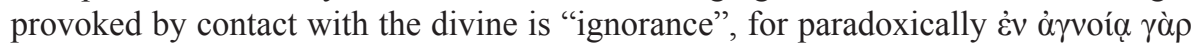

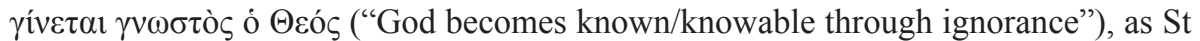
Dionysius the Areopagite states.
\end{abstract}

Keywords: Paradox; aporia; oxymoron; atopon, thaumazein; mirabilia; religious paradox; Homer; Hesiod; Archilochus; Heraclitus; Plato; Euripides Bacchae; ancient mysteries; Zeno of Elea; the Gospel of St John; Akathistos Hymnos; Virgin Birth.

\footnotetext{
${ }^{1}$ Warm thanks are due to Professora Maria Cecília de Miranda Nogueira Coelho for the invitation to give the paper on which this article is based, and for her helpful comments. For invaluable feedback I wish also to thank the members of the audience; the anonymous referee of Nuntius; Professor Smaro Arabatzi- Nikolaidou of the Democritus University of Thrace; Dr Agis Marinis of the University of Patras; Metropolitan Emeritus Chrysostomos and Father Chrysostomos of Etna, CA; and Father John Raffan of Athens.
} 
Resumo: Abordando o paradoxo religioso e metafísico - assunto, aliás, estranhamente bastante negligenciado -, este artigo investiga exemplos em fontes da literatura grega antiga e do início do Cristianismo, alguns bem conhecidos; outros menos. O paradoxo religioso é destacado em textos que vão de Hesíodo, Arquíloco, Heráclito e as Bacantes, de Eurípides, ao Evangelho de São João, São Paulo e Akathistos Hymnos, do século VI, em honra à Virgem Maria. Aporia, na esteira do paradoxo religioso, confirma a limitação humana e aponta para a transcendência do divino. O Cristianismo, a religião, por excelência, do paradoxo, reconhece a impossibilidade de oferecer "soluções" filosóficas para os paradoxos e aporias do dogma e recorre ao oximoro e paradoxo como a única forma adequada de expressão. O único recurso diante do estranho deslocamento da ordem e da lógica provocado pelo contato com o divino é a "ignorância", pois,

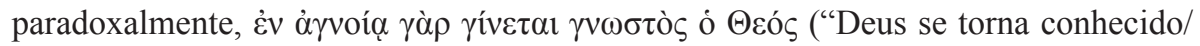
conhecível por meio da ignorância"), como afirma São Dionísio Aeropagita.

Palavras-chave: Paradoxo; aporia; oximoro; atopon, thaumazein; mirabilia; paradoxo religioso; Homero; Hesíodo; Arquíloco; Heráclito; Platão; Eurípides Bacantes; mistérios antigos; Zenão de Eléia; São Paulo, São Dionísio Aeropagita; Akathistos Hymnos; Nascimento virginal.

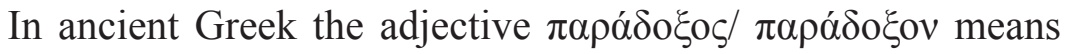
'contrary to expectation, incredible'-that is, contrary to, or beyond, the assumption that nature follows predictable patterns. Citing examples mainly from nature and everyday experience, Aristotle demonstrates in the $2^{\text {nd }}$ book of his Art of Rhetoric two types of argument, one based on the

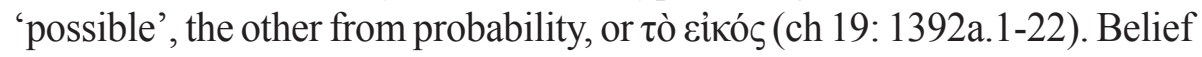
in the existence, for instance, of Centaurs, the Chimaira or the Gorgons

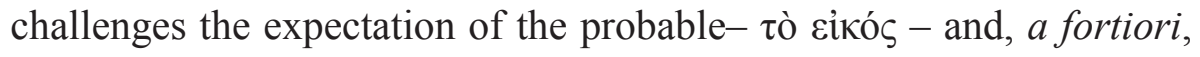
the possible in normal conditions. ${ }^{2}$ Paradoxa, because they supersede and frustrate everyday expectations, can be reckoned to be thaumasta or thaumasia ('wonderful, marvellous'); ${ }^{3}$ they perplex us, leading to the condition of thaumazein ('wonder, marvel') and more generally to

\footnotetext{
2 Plato, Phaedrus 229 c-d.

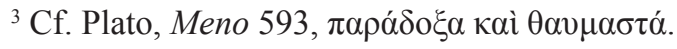


aporia, ${ }^{4}$ a sense of being at a loss. ${ }^{5}$ In its extreme form, aporia recalls the confusion and wonder brought about by an experience of the divine. Unlike philosophical aporia (as I understand it), which is open-ended (but in Plato is ultimately solvable), religious aporia offers no intellectual or philosophical way out. It traps us in a labyrinth of bafflement. In this paper I intend to look at ancient Greek and early Christian examples of metaphysical or religious paradox and concomitant aporia. Paradox of this kind is a huge and strangely neglected field. ${ }^{6}$ My comments will, I hope, cast fresh illumination on well-known instances, and bring little known examples to light. It is as well to bear in mind that each of these instances would lend itself to an entire series of articles.

Paradoxes have always come in many shapes and sizes. The earliest example of one type occurs in Odyssey, IX, $401 \mathrm{ff}$. Polyphemos the Cyclops has just been blinded by Odysseus and his men. Odysseus has previously revealed his name to be Oũtı// 'Nobody' (364ff.). The monster howls in pain, prompting the other Cyclopes to rush to his cave and to ask him what the matter is; Cyclops answers quite truthfully that "Nobody is trying to kill me". Whereupon the Cyclopes conclude in unison that Polyphemos is the victim of mental disease $(411$, voṽ $\sigma \circ)$ sent by Zeus." The statement "Nobody is trying to kill me", under the

\footnotetext{
${ }^{4}$ Aporia and wonder are identical states in Plato, Symposium 208b; see also immediately below. In Theaetetus 155c et passim 'wonder'/ thauma (thaumazein) is "sudden and frontal bewilderment", a state of suffering--of disorientation and dizziness signalling intellectual pregnancy, as S. Chrysakopoulou (2012, p. 6) notes. Producing the same constellation of painful physical and psychological effects (or symptoms) as those caused by Eros, thaumazein precedes and accompanies (re)initiation, through "midwifery", into the invisible realities of knowledge. Thus philosophy, according to Plato, begins and ends with thaumazein; cf. Aristotle Metaphysics 982b. For full treatment see Chrysakopolou (2012, p. 11 ff.); and Nightingale (2001, p. 23-58).

5 Aporia means literally 'without passage, lacking ways and means' (in a geographical/ physical sense) and hence figuratively 'being at a loss' (primarily an economic metaphor in English), and is personified as Penial 'Poverty', the mother of Eros in Plato's Symposium (203b4). As said, aporia is equated with thaumazein in the dialogue (Symposium 208b); see below.

${ }^{6}$ Status quaestionis and bibliography of religious paradox in Yusa (1995, p. 194-195).

${ }^{7}$ Cf. Euripides, Cyclops 549, 672 ff.
} 
circumstances, is so illogical that it must be the result of mental affliction. This humorous example is an instance of W. V. Quine's veridical paradox (QUINE, 1976, p. 1-18). It shows how a paradox engenders aporia; one means of escape from aporia is to assume that the suspension of the rules of everyday logic reflects insanity or, ultimately, the handiwork of a god.

A special class of paradoxon, in the narrower sense of selfcontradiction, is the mathematical and philosophical arguments associated with Zeno of Elea (fl. ca 460 BC) and the Stoics. ${ }^{8}$ Perhaps the most notorious is the logos, or argument, of "Achilles and the Tortoise". Aristotle, our main source, calls it "The Achilles" (o 'A $\chi 1 \lambda \lambda \varepsilon v ́ \varsigma)$; I quote the opening sentence of the philosopher's account of the paradox: "The

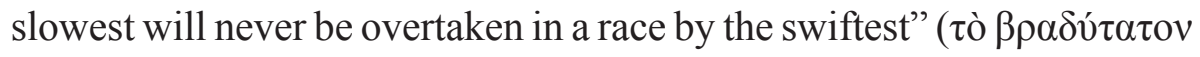

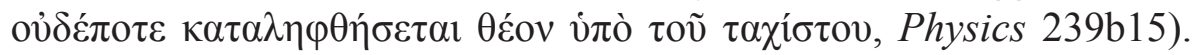
How bizarre (at least on first thought)! How unreasonable, especially as the competitors in Zeno's argument are Achilles, reputably the fastest runner in myth, and a tortoise. This is a mathematical conundrum (which I leave to specialists to explain); but its surprising absurdity is merely superficial, for, as an eminent mathematician has put it, "In mathematics there is no paradox". "If the layman cannot understand Zeno's logos, this is because he or she lacks the proper conceptual paradigm to decode it.

Contradictory propositions such as the paradox just cited can prove true, but sometimes they are genuinely preposterous (and even absurdly funny, as in the rhetorical praise of unworthy topics such as fever, gout, baldness, adultery, vomit, dung, and death). ${ }^{10}$ The domain of the absurd lies out of the way, beyond normality, in a heterotopia; hence the Greeks also called paradoxes and oxymora "atopa". ${ }^{11}$ Cyclops, inverting as he does social codes and conventions, inhabits the fantasy

\footnotetext{
${ }^{8}$ Booth (1957, p. 187 ff.) on the paradox; Sorabji (1983, ch. 21) on Zeno's paradoxes. ${ }^{9}$ Michalis Dafermos (of Princeton University), viva voce.

${ }^{10}$ Menander Rhetor 346. 9-23 (Russell-Wilson); cf. Gorgias' Encomium of Helen, Alcidamas' Encomium of Death, and Lucian's Encomium of a fly.

${ }^{11}$ In Plato's Philebus 49 the adjective atopos refers to childish envy as an instance of a

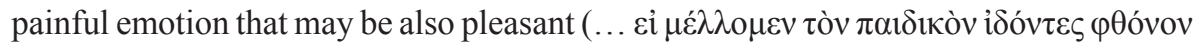

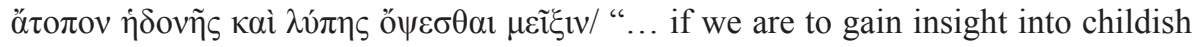
envy with its absurd mixture of pleasure and pain.”).
} 
world of the atopon, the veritable 'placeless'. Flouting the laws of xeinia, Polyphemos eats his guests rather than treating them to a meal. Atopa, in the general sense of 'absurd or abnormal things or events', may characterise places and peoples we would call "outlandish". Antonius Diogenes, probably dating to the $2^{\text {nd }}$ century AD (at the time when the New Testament was crystalising as a text), wrote a labyrinthine novel that was a parody of travel-fantasy. Early on, the heroine Derkyllis travels to Iberia where, the narrator tells us, "she came to a city where people could see in the dark but were blind by day" (WINKLER-STEPHENS, 2014, p. 123-124, 109b3). The inhabitants of this strange city invert normality; the city is, one might say, atopos, i.e. not on the map of normality.

Paradox, in its broader and narrower senses (as 'incredible' or 'self-contradictory' respectively), is the stuff for religion. As K. Patton states, "Paradox is the rule, not the exception in religion" (PATTON, 2009, p. 180). By which this historian implies that religion is hospitable particularly to contradictions in terms, such as the dogma - an oxymoron, or compressed paradox-- that Christ is fully human and yet also divine, and (I might add) the "absurd" proposition, at least at first sight, that the three persons of the Holy Trinity in reality comprise one being, to wit, $1+1+1=1$. Unlike the case of Zenon's paradox, the Holy Trinity is incomprehensibly puzzling because human beings lack the cognitive language to explain its surface contradictoriness (see below). If I may offer a generalisation: Religion addresses itself, either explicitly or by implication, to the chaotic world at the core of which lies paradox. Chaos, notes the anthropologist Clifford Geertz, takes the form of "a tumult of events" that threatens man's "analytic capacities", "powers of [sc. physical] endurance", and "moral insight" (GEERTZ, 1966, 14). "Bafflement", he goes on to say, "suffering, and a sense of intractable ethical paradox" challenge the "proposition that life is comprehensible" (GEERTZ, 1966, p. 14). Because, as Geertz observes, man cannot cope with chaos (and corollary paradoxa), he turns to religion, and the Greeks were no exception. Their divinities suffused this disordered physical and moral universe either abstractly or as anthropomorphic forces. They caused wondrous or awe-inspiring, unbelievable events and phenomena, 
i.e. 'miracles', or they tolerated, in the relative short term, the paradox of the suffering of the innocent and the prospering of evildoers. To cite two mirabilia: In Iliad, XX, 344-348 Achilles describes the sudden disappearance of Aineias from the battlefield as a thauma/ 'marvel' (344), and puts this down to the workings of a deity:

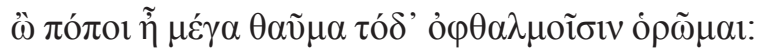

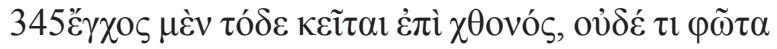

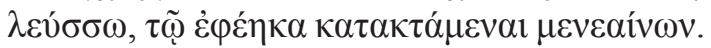

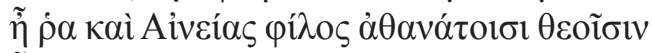

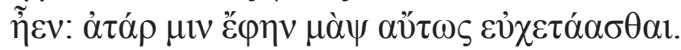

"Now look, truly a great marvel is this that my eyes behold.

[345] My spear lies here upon the ground, yet I cannot see the man at whom I hurled it, eager to slay him.

Truly, it seems, Aeneas too is dear to the immortal gods, although I thought that his boasting was idle and vain." 12

Archilochus also conjures a thauma, here an outright natural paradoxon, which seems to him to occur praeter naturam. His fr. 122 $\mathrm{W}$ famously records a solar eclipse, possibly dating to spring $648 \mathrm{BC}$ :

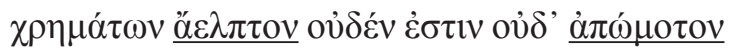

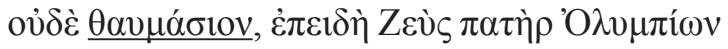

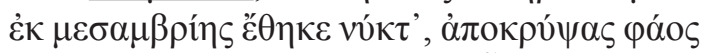

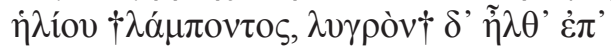

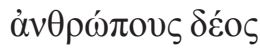

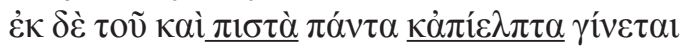

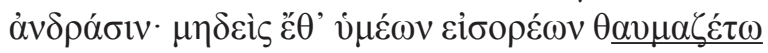

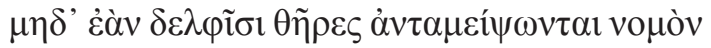

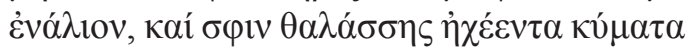

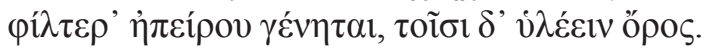
10 A $\rho] \chi \eta v \alpha \kappa \tau i \delta \eta \varsigma]$

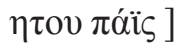
$\tau v \theta \eta \gamma \alpha \dot{\alpha} \mu \omega 1$

${ }^{12}$ Perseus text and (modified) tr. 
Nothing is to be unexpected or sworn impossible or marvelled at, now that Zeus father of the Olympians has made night out of the noonday, hiding away the light of the shining sun, and clammy(?) fear came over people. From now on, men can believe and expect anything; let none of you any longer marvel at what you see, not even if wild animals take on a briny pasturage in exchange with dolphins, and the crashing waves of the sea become dearer to them than the land, the wooded mountain dearer to dolphins... Archeanactides... child of... marriage... ${ }^{13}$

The poet says in effect that an impossible reversal has become possible, Zeus turning midday into night (3); to his mind this raises the possibility of further reversals of nature, all of them paradoxical adynata. The vocabulary of "paradox" is conspicuous in the first lines of the elegy:

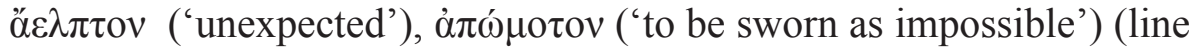

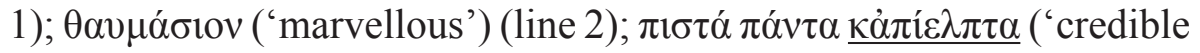
and expected') (line 5); and $\theta \underline{\alpha v \mu \alpha \zeta \dot{\varepsilon} \tau \omega}$ ('marvel' [imper.]) (line 6). The powerful hand of Zeus is responsible for the eclipse. Plato would agree that something supramundane is afoot, and would go a step further by acknowledging that the thauma reflects the incorporation of the supreme

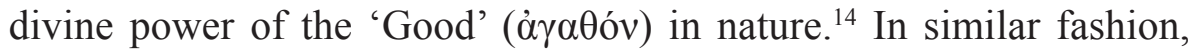
Heraclitus and most Presocratics, as well as Hippocrates, assume that behind natural wonders and incomprehensible events and all other paradoxa lies divine agency. ${ }^{15}$

The extraordinary events that the gods bring about are generally contrary to the laws of logic or normality; at their most dramatic, they involve jarring symmetrical reversals of nature such as the turning of the midday light into darkness as in Archilochus. At times Zeus is said to successively perform mutually exclusive, contradictory actions in order to uphold morality. Gods and daimones, in keeping with a theological (and magical) principle well-attested in Greek literature and other sources, can effortlessly carry out an action, let us call it " $\mathrm{A}$ ", and just as easily its exact, symmetrical opposite, "-A". As Hesiod advertises in his hymn to

\footnotetext{
${ }^{13}$ Text \& tr. in Gerber (1999, p. 161, 163).

${ }^{14}$ See n. immediately below.

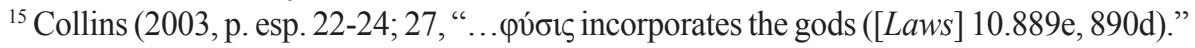


Zeus in the proem of the Works and Days, "For easily he makes strong, and easily he oppresses the strong,/ easily he diminishes the conspicuous one and magnifies the inconspicuous,/and easily he makes the crooked

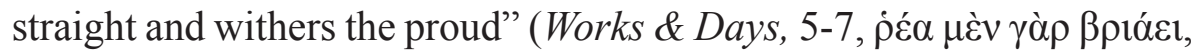

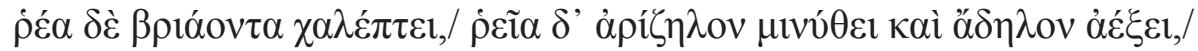

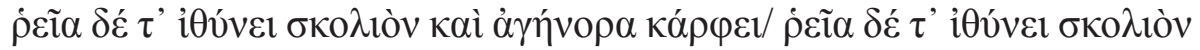

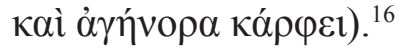

These polar formulations and imagery not only celebrate the Justice of Zeus, but also lend insight more generally into the power and unpredictability of the gods as agents of chaos. Paradox as a concept originated, I suggest, from religious speculation, from thinking about the mysterium tremendum et fascinosum of the gods. Their deeds and actions tend to be "incredible-but-true"; no greater proof of their power exists than the fact that quite often these actions amount to sweeping reversals. Consider again Hesiod's precept, "Zeus can (capriciously) diminish the

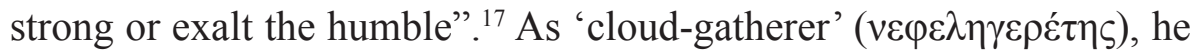
can also herald fair weather or cause a storm, although not, it seems, at the same time. An analogue to Zeus' bipolar potentiality is provided by Hermes, who, according to Iliad, XXIV, 343 ff., uses his magical wand to charm people to sleep or alternatively to rouse them. In Odyssey X he goes to Kirke's isle with the mission of liberating Odysseus from her clutches. He holds his wand, which is now said to be golden (X, 277). Hermes gives the hero a magical herb-a "good drug" ( 291), as he touts it--to neutralise the witch's magic potion, her kukeôn (which is actually a 'posset'). It is interesting that Hermes' pharmakon, termed molu by the gods (305), has a black root but a milk-white flower (304). Only gods can pull it out of the ground with ease (304-5), for (in the words of Odysseus) "the gods can do anything" (306). Like any potent drug, the herb is ambivalent, hence it is black and white; but this

16 Tr. West (1988, p. 37). Cf. Greek and Latin parallels in West (1978, p. 139-40) ad Works \& Days, $5 \mathrm{ff}$.

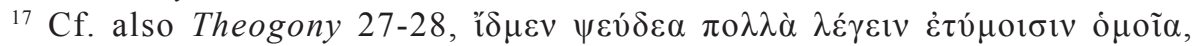

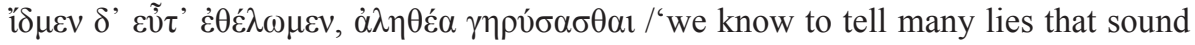
like truth,/ but we know to sing reality, when we will', tr. West $(1988$, p. 3). 
coincidentia oppositorum also sums up the ontology of the gods, who sometimes deal in pairs of contrary alternatives that are easy as pie. If a god enacts A and then its opposite, - A, the two antithetical strands in his supernatural repertoire make up a paradox.

From theological (in effect, psychological) paradox, it was but a small step to Heraclitus' fundamental principle of "unity and diversity" and his use of paradox in an attempt to explain the eternal, ever-changing kosmos. ${ }^{18}$ In his Refutation of all heresies, Hippolytus, the $2^{\text {nd }}$ century Christian apologist, gives numerous examples of Heraclitean paradoxes: ${ }^{19}$

...Heraclitus says that dark and light, bad and good, are not different but one and the same...

"The path up and down is one and the same." [B 60, ódòs öv

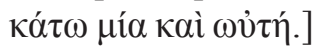

...And he explicitly says...

"Immortals are mortals, mortals immortals: living their death,

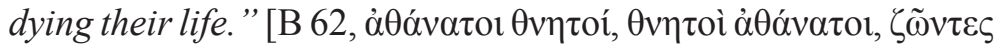

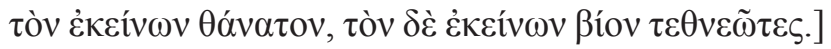

Aristotle found the Ephesian philosopher's reliance on paradox something of a paradox. As he puts it (Metaphysics 1062a $31 \mathrm{ff}$.), "If someone had questioned Heraclitus... he might perhaps have compelled him to agree that contradictory statements can never be true of the same subjects." Aristotle may be right, as G.E.R. Lloyd and others have argued, inasmuch as Heraclitus may have defined and qualified his opposite terms

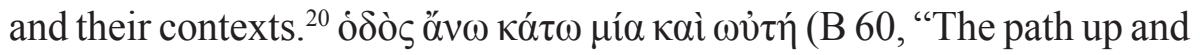
down is one and the same.") may have meant, for instance, that an object on a mountain slope is "down" when viewed from the summit; seen from the foot of the mountain, it is "up". His contradictions vanished when his statements were qualified relationally (and possibly also when set in the context of incessant motion, cf. his famous, if often ill-construed

\footnotetext{
${ }^{18}$ See esp. McKirahan (1994, p. 134-139); Osborne (1997, p. 88 ff., esp. 102 ff.).

${ }^{19}$ Book X of Hippolytus' work, which circulated separately by Photius' time, was entitled "Labyrinth" from its opening statement, "I have broken through the labyrinth of heresies".

${ }^{20}$ Lloyd (1966, p. 102).
} 
"everything is in flux", cf. B 12 and 91). ${ }^{21}$ The Ephesian philosopher may have been experimenting with antinomies (as logicians call them) rather than using them in an actual sense as a first principle. However that may be, it is, I believe, significant that Heraclitus was resorting to the formulation of antinomies in the first place to explain the baffling kosmos.

Although he levels criticism at popular religion, it is fairly clear, as M. Adoménas has proposed, that the philosopher also used the Dionysiac mysteries and other religious rituals to demonstrate, e.g. in B 15, the seemingly paradoxical structure, or logos, of the universe (ADOMÉNAS, 1999, esp. p. 91, 101, 113). Heraclitus held that this logos was also articulated in secular practices and institutions. Perhaps this Presocratic, far from simply detecting paradox at work in ritual and society, actually inferred it as a comprehensive principle from religious thinking in particular.

Paradoxa in the sense of intriguing antinomies or other contradictions may have been common in ancient mystery cults. Despite the paucity of the surviving written evidence of such cults, Euripides' Bacchae may nevertheless furnish indirect evidence. The play is an exercise in paradox, for Dionysus (to quote A. Henrichs), is "essentially a paradox, the sum total of numerous contradictions" (HENRICHS, 1979, p.3). Bacchus is, first of all, a true god, though the son of a mortal, Semele, and Zeus (1 ff., 335, etc.); he is both god and mortal - a paradox that recalls the fully human and fully divine nature of Christ. As a foetus snatched from his mother's womb, he gestated in

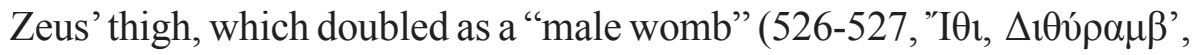

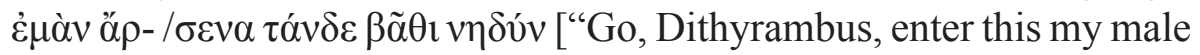
womb"]), another contradiction. In the beginning of the play, Teiresias praises Dionysus, inventor of wine, alongside Demeter, provider of bread to mankind; in the course of his parallel encomia, the prophet

\footnotetext{
${ }^{21}$ McKirahan (1994, p. 143-144): Heraclitus upholds inherent stability and continuity rather than radical change into diametrical opposites. Cf. Hussey (2000, p. 633-634): Heraclitus' "oppositions cohere so closely that they are mutually inseparable in thought or experience, that they need one another...Each unity, then exhibits...a systematic ambivalence, as between two opposites."
} 
says something so paradoxical that some scholars have cast doubt on the passage (284-285):

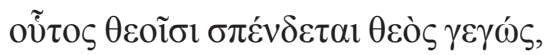

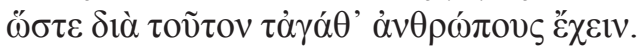

He, being god, pours a libation [middle voice]/ is poured as a libation [passive voice] to the gods,

so that through him mankind might receive blessings.

'Being (a) god' ( $\theta \varepsilon$ ò $\varsigma \varepsilon \gamma \omega \dot{\varsigma} \varsigma)$ may have a concessive force: though a god himself, Bacchus, rather than receiving a libation, offers one to the gods; in fact, he passively becomes a libation to the gods, because he is identical with the wine used in libations. Whether $\sigma \pi \varepsilon \dot{\varepsilon} \delta \varepsilon \tau \alpha$ is middle or passive, there is the customary distinction here between pouring and receiving; either way, Dionysus, indwelling in the wine, ${ }^{22}$ is sacrificed to other gods for the good of mankind. R. Seaford detects an allusion to the mystical role of wine in the mysteries, and I agree (SEAFORD, 1996, p. 176 ad 283-284). Not only does this passage "reflect or refract mystic instruction", as Seaford suggests, it also evokes a deep paradox. In a number of vases from the late archaic period on, gods, including Dionysus and even Zeus, offer libations or perform other forms of sacrifice without any recipient (s) depicted. K. Patton argues that the gods are sacrificing to themselves, and that these cases of pure reflexivity, typical of the paradoxes associated with religion, serve as a prototype of "religiousness". ${ }^{23}$ In Euripides the sacrificial act of the god, however, not only has recipients, but also explicit beneficiaries. We are dealing with something slightly different from the divine self-reference of the vases and more akin to Christ's self-sacrifice as it is interpreted by St Paul in Philippians 2:6-7: ôs \&̇v $\mu о \rho \varphi \tilde{n} \Theta \varepsilon \circ \tilde{v}$

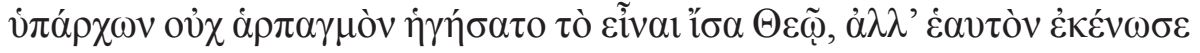

\footnotetext{
${ }^{22} \mathrm{He}$ is not just a metonymy for wine. Cf. Dodds (1960, p. 106) on addressing a person or a drink in Hindu ritual.

${ }^{23}$ Patton (2009, p. esp. 7-9, Zeus' libation to himself); 13, 316 (the paradox of divine reflexivity is the defining element of the divine); 313-315 (the gods, the sources of sacrifice, carry out perfect sacrifice in perpetuity); 71-73 (in a red-figure Attic kantharos by the Nikosthenes Painter [ca 520-510 BC] Dionysus pours a libation over an altar; he does the same in an Attic red-figure kylix by Douris [ca $480 \mathrm{BC}])$.
} 


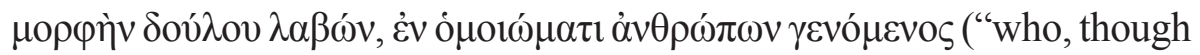
he was in the form of God, did not count equality with God a thing to be grasped, but emptied himself, by taking the form of a servant, being born in the likeness of men"). ${ }^{24}$ The paradox of gods offering to gods is axiomatic not only for the ancient world but even more so for Christianity. Christ, albeit God, foregoes equality with God, emptying himself figuratively, like a vessel filled with water, in order to shed his blood on the cross; in similar vein, according to the Synoptic Gospels, the Gospel of St John, and early Church Fathers, he variously becomes a sacrificial lamb, goat, heifer, even a scapegoat for the sake of mankind. ${ }^{25}$ In the Divine Liturgy of both Sts John Chrysostom and Basil the Great, the priest utters in a

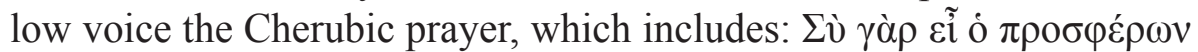

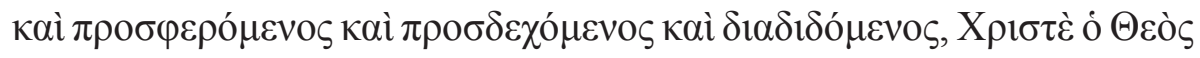
$\dot{\eta} \mu \tilde{\omega} \nu$ ("For you are the one who offers and is offered, who receives and is distributed, Christ our God"). ${ }^{26}$ Dionysus, by the same token, becomes a libation to the gods, paradoxically combining the roles of god and victim for the good of man. ${ }^{27}$

I now come to another paradox, the central one in the play. Bacchus arrives at Thebes disguised by means of a mask as a young beardless devotee of himself. Pentheus denounces him as a $\theta \eta \lambda u ́ \mu о \rho \varphi o v$ $\xi \dot{\varepsilon}$ vov/ a "girlish stranger" (353) rumoured to have blonde curls and a wine-red complexion (235-236). He is in fact a travesty, a contradiction in terms. ${ }^{28}$ The delicate externals mask a paradox, for he is alike the ephebic inventor of wine that soothes, and an agent of the violent mania caused by wine and ecstasy; a passive, suffering god, but also a brutal avenger. At the end the chorus call upon Dionysus to make an epiphany

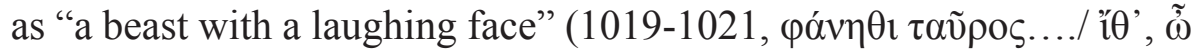

\footnotetext{
${ }^{24}$ English Standard Version (ESV).

${ }^{25}$ On Christ's “auto-sacrifice” cf. Patton (2009, p. 241-243), who does not cite Bacchae 284-285.

${ }^{26}$ In Matthew 26: 26-28 and Hebrews 7: 26-27, Christ is High Priest and victim alike: another paradox.

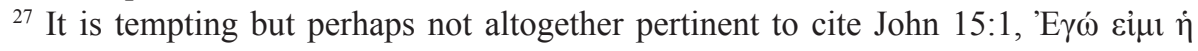

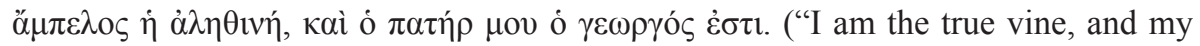
Father is the vinedresser.").

${ }^{28}$ Seaford (1996, p. 180) on transvestite Dionysus.
} 


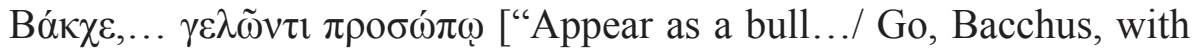
a laughing face"]). ${ }^{29}$ 'Face' here may also mean 'mask'; however that may be, a savage beast with a laughing 'face' (or 'mask') is another contradiction that shows up this god's ambivalence. (Perhaps when he appears ex machina at the very end [Bacchae 1330], the god has changed his mask and costume. If so, he now appears as the bearded, mature male familiar from earlier iconography.) $)^{30}$

The transformation of Dionysus in the course of the action from $\mathrm{A}$ (a seductive, soothing androgyne) to - A (a mature, masculine avenger) is nothing short of miraculous. As said, it may well be that the prominence of mirabilia in the Bacchae corresponds to the ecstatic, "otherworldly" experiences, perhaps including hallucinations promoted in mystery cults. The terms thaumata and thaumasia are used several times in the Bacchae to denote the violent superhuman feats of the ecstatic women worshippers and Dionysus during their oreibasia $(667,716,1063 \mathrm{ff}$., cf. 764, 785-786). The exodus of women from the protective polis was itself a paradoxical reversal of norms.

As noted in passing, Christianity is the religion of paradox par excellence; I should like to conclude with a few more examples from the early Christian and early Byzantine periods. If we look at Christian paradoxes, we might gain insight into ancient religion and possibly the mysteries. For lack of evidence, Walter Burkert leaves open the question whether the emphasis of the new religion on paradox reflects the influence of pagan mysteries. ${ }^{31}$ Inter alia, the conflation, however, of titles of gods and incongruities such as Zeus katachthonios, viz. 'Zeus Lord of Death'

${ }^{29}$ At Bacchae 439 the god is a gentle beast surrendered to his captors and has an enigmatic smile; see Dodds (1960, p. 131) ad loc.

${ }^{30}$ But cf. Foley (1985, p. 249-250, 252-253): there is no change of mask; rather, the smile is variously (mis)interpreted by the characters in the course of the play.

${ }^{31}$ See also Burkert (1987, p. 101) on the "dynamic paradox of death and life in all the pagan mysteries associated with the opposites of night and day, darkness and light, below and above". For a less skeptical view of the reception of the Bacchae and associated cults by the early Church, see now Friesen (2015). Paradoxical formulations may have been key in Orphism. The Derveni papyrus mentions, for instance, that Orpheus taught through "riddles", which may have lent themselves to paradox. 
(Iliad IX, 457), may support a greater degree of paradox than we might suspect. Sustained paradox, at any rate, begins in earnest with St Paul and the Evangelists, as noted. St John proclaims the supreme paradox

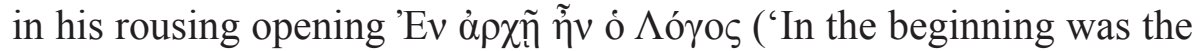
Word'): the transcendent Word of God became flesh, that is, material and contingent. The sublime became lowly, a paradox reflected also in the stylistic lowliness and simplicity of the first specimens of Christian literature, which purportedly expressed sublime subject matter. ${ }^{32}$ The new religion threw into relief the everyday paradox of living in this world while aspiring to the other. The paradox of God becoming flesh is encapsulated in the related paradox of the Virgin Birth of Christ. In the Byzantine Akathistos Hymnos, probably dating from the early $6^{\text {th }}$ century, ${ }^{33}$ Mary tells the Archangel Gabriel that his voice (and, by extension, his message of the Annunciation) is a paradox: $\tau$ ò $\pi \alpha \rho \alpha ́ \delta o \xi o ́ v$ бov $\tau \tilde{\eta} \varsigma \varphi \omega v \tilde{\eta} \varsigma$ ("the paradox of your voice") (AKATHISTOS HYMNOS, 1998, p. 49). The hymn exalts the Virgin Birth in philosophical terms:

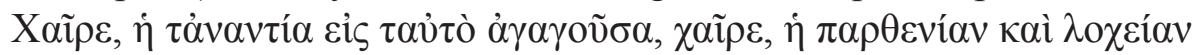
$\zeta \varepsilon v \gamma v \tilde{\sigma} \sigma \alpha$ ("Hail, You who has joined contraries. Hail, you who has conjoined virginity with parturition"). (AKATHISTOS HYMNOS, p. 61). ${ }^{34}$ This event infringes Aristotle's law of contradiction. In the course of the hymn, the lector praises Mary for "having united God-Logos

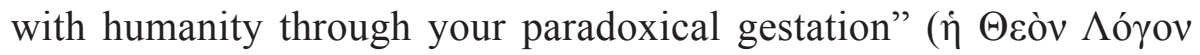

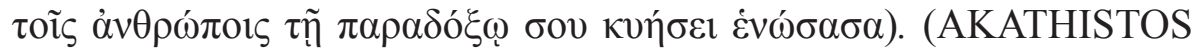
HYMNOS, p. 77).

Early Christians generally used the trope of the paradox to express the "otherness" and power of divinity that shock one into uncomprehending speechlessness. Again, to cite the Akathistos Hymnos, "Rhetors full of sounds turn into voiceless fish on your account,

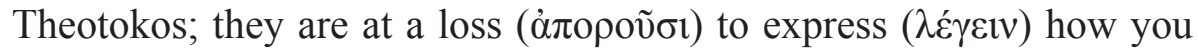

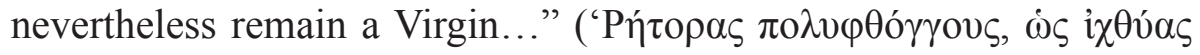

\footnotetext{
32 Thus Auerbach (1965, p. 52): “...the sublimity of the subject matter shines through the lowliness."

${ }^{33}$ Oxford Dictionary of Byzantium, s.v. 'Akathistos Hymn'.

${ }^{34}$ Translations of the hymn are by me.
} 


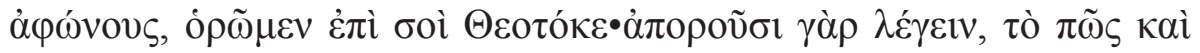

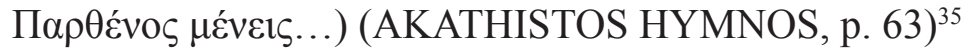

Christianity acknowledges the impossibility of offering philosophical "solutions" to the aporiai and paradoxes of dogma, and resorts to oxymoron and paradox as the only adequate form of expression. Insoluble "riddles" such as the Virgin Birth reduce the Christian to ignorance and bafflement that is nothing but aporia. To quote once again the Akathistos Hymnos, "Having seen this strange/ xenos childbirth [sc. the Virgin Birth], let us estrange ourselves from this world ( $\xi \varepsilon v \omega \theta \tilde{\omega} \mu \varepsilon v$

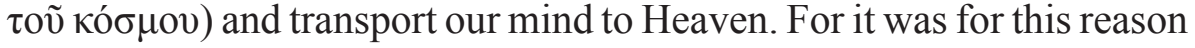
that God sublime appeared as a humble human being upon the earth."

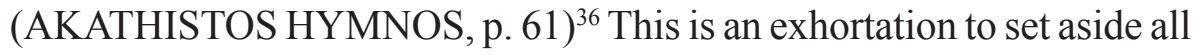
earthly concepts (including those of philosophy) when approaching the mysteries of God. The only recourse before the estranging dislocation of order and logic provoked by contact with the divine is "ignorance", for

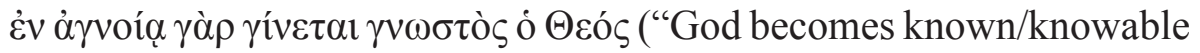
through ignorance"), as Dionysius the Areopagite states in On the Divine Names (PG 3:664C). ${ }^{37}$ This is neither the ignorance of the uneducated nor the failed, learned kind, but rather the ignorance at which we arrive by eliminating all concepts, since the Godhead transcends anything we

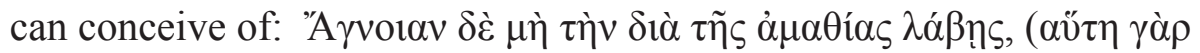

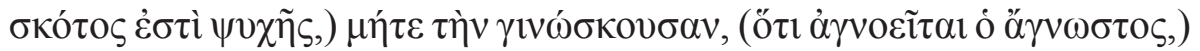

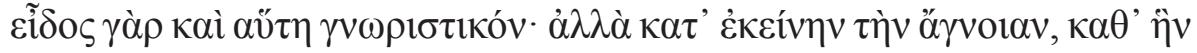

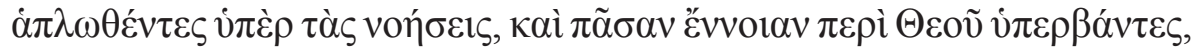

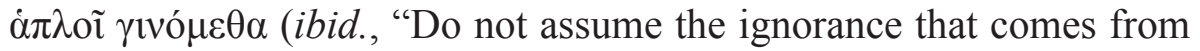
lack of education (for this is darkness of the soul), nor the perceiving kind

${ }^{35} \mathrm{Cf}$. in non-religious contexts the oxymoron kennings in Aeschylus Seven against

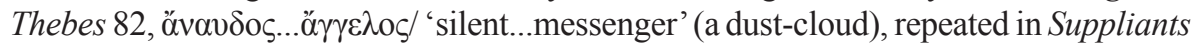

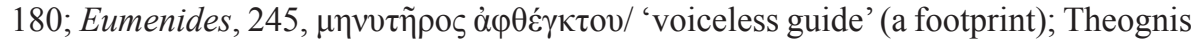

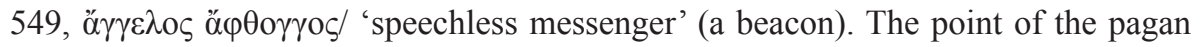
passages is however different: something inanimate speaks volumes, as it were.

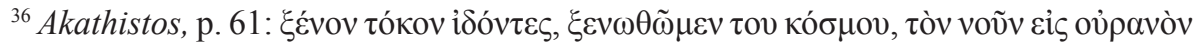

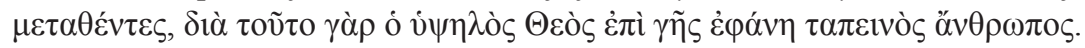

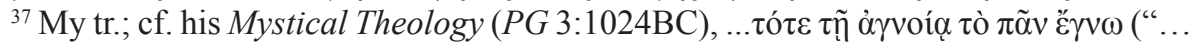
then through ignorance he came to understand everything"). 
(because He who is unknown is unknownable), for this too is a cognitive kind; but rather the ignorance in which, after expanding ourselves beyond conceptions and having surpassed every notion about God, we become simple."). ${ }^{38}$ The utter simplicity urged by the Areopagite leads us, paradoxically, to knowledge of the unknowable.

Since antiquity, then, paradox has characterised not merely ritual sacred actions and accompanying prayer, but also other related genres and media, including religious iconography. In paganism, mirabilia and, especially, wondrous contradictions associated with the gods reflect a world rife in physical, intellectual, and ethical inversions and antinomies. Confusion, aporia, and wonder follow in the wake of miracles and contradictions worked by the gods. Religious paradox has thus always been a cipher for the unintelligible, transcendent divine, the unbridgeable "otherness" of the gods or God. Christianity has self-reflexively defined itself from the first as the religion of paradox. Multiplying self-contradictory propositions and taking them to greater heights, the new faith has converted paradox into a trademark, as it were, of its transformative uniqueness, its turning of the tables on the world. Logic and all earthly conceptual paradigms collapse under the new dispensation, and paradox shows up man's permanent state of aporia. Indeed, as many theological texts indicate, the Christian God transcends any notion of existence; so, when we think we have begun to have some understanding of Him, it is not God whom we have understood. This is the supreme paradox.

\section{References}

ADOMÉNAS, M. Heraclitus on Religion. Phronesis, Leiden \& Boston, v. 44, n. 2, p. 87-113, 1999.

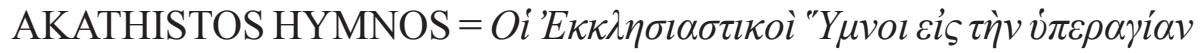

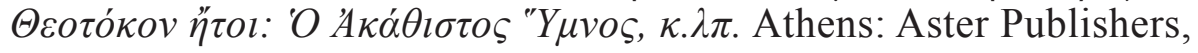
1998.

${ }^{38}$ My translation. 
AUERBACH, E. Literary Language and Its Public in Late Latin Antiquity and in the Middle Ages. Engl. tr. Cambridge: Cambridge University Press, 1965.

BOOTH, N. Zeno's paradoxes. Journal of Hellenic Studies, Cambridge, v. 77, n. 2, p. 187-201, 1957.

BRODERSEN, K. (Tr. \& ed.). Die Wahrheit über die Griechischen Mythen. Palaiphatos' "Unglaubliche Geschichten". $3^{\text {rd }}$ edn. Stuttgart: Reclam, 2017.

BURKERT, W. Ancient Mystery Cults. Cambridge, MA: Harvard University Press, 1987.

CHRYSAKOPOULOU, S. Wonder and the Miraculous in Ancient Philosophy. In: VASSALOU, S. (Ed.). Practices of wonder. Cambridge: James Clarke \& Co, 2012. p. 88-120.

COLLINS, D. Nature, Cause, and Agency in Greek Magic. Transactions of the American Philological Association, Baltimore, v. 133, n. 1, p. 1749, 2003.

DIONYSIUS THE AREOPAGITE, ST. On the Divine Names. In: MIGNE, J. P. (Ed.). Patrologia Graeca, Paris, 1857-66, v. 3: 664C.

DIONYSIUS THE AREOPAGITE, ST. Mystical theology. In: MIGNE, J. P. (Ed.). Patrologia Graeca, Paris, 1857-66, v. 3: 1024BC.

DODDS, E. R. Euripides Bacchae. Edited with an Introduction and Commentary. $2^{\text {nd }}$ edn. Oxford: Oxford University Press, 1960.

FOLEY, H. P. Ritual Irony: Poetry and Sacrifice in Euripides. Ithaca; London: Cornell University Press, 1985.

FRIESEN, C. J. Reading Dionysus: Euripides' Bacchae and the Cultural Contestations of Greeks, Jews, Romans, and Christians. Tübingen: Mohr Siebeck GmbH \& Co., 2013.

GEERTZ, C. Religion as a culture system. In: BANTON, M. (Ed.). Anthropological Approaches to the Study of Religion. London:Tavistock, 1966. p. 1-46. 
GERBER, D. E. Greek Iambic Poetry: From the Seventh to the Fifth Centuries BC. Cambridge, MA; London: Harvard University Press, 1999. (Loeb Classical Library).

HACKFORTH, M. T. Solved by Walking: Paradox and Resolution in the Labyrinth, 2012. Dissertation (PhD) - Pacifica Graduate Institute, 2012.

HENRICHS, A. Greek and Roman Glimpses of Dionysos. In: HOUSER, C. (Ed.). Dionysos and His Circle: Ancient Through Modern. Catalogue of an Exhibition. The Fogg Art Museum. Cambridge, MA: Harvard University Press, 1979. p. 1-11.

HUSSEY, E. Heraclitus. In: BRUNSCHWIG, J.; LLOYD, G. E. R. (Ed.). Greek Thought. A Guide to Classical Knowledge. Engl. tr. Cambridge, MA; London: Harvard University Press, 2000. p. 631-641.

KAZHDAN, A. P. (Ed.). Oxford Dictionary of Byzantium. Oxford: Oxford University Press, 1991.

LLOYD, G.E. R. Polarity and analogy. Two Types of Argumentation in Early Greek Thought. Cambridge: Cambridge University Press, 1966.

McKIRAHAN, Jr, R. D. Philosophy Before Socrates. An Introduction with Texts and Commentary. Indianapolis; Cambridge: Hackett, 1994.

NIGHTINGALE, A. W. On Wandering and Wondering: Theôria in Greek Philosophy and Culture. Arion: a Journal of Humanities and the Classics at Boston University, Boston, v. 9, n. 2, p. 23-58, 2001.

OSBORNE, C. Heraclitus. In: TAYLOR, C. C. W. (Ed.). Routledge history of philosophy. London; New York: Routledge, 1997. v. I: From the beginning to Plato, p. 88-127.

OTTO, R. The Idea of the Holy: An Inquiry into the Non-Rational Factor in the Idea of the Divine and its Relation to the Rational. Engl. tr. Revised with additions. Oxford: Oxford University Press; London: H. Milford, 1950.

OXFORD Dictionary of Byzantium. Oxford: Oxford University Press, 1991.

PATTON, K. C. Religion of the Gods. Ritual, Paradox, and Reflexivity. Oxford; New York: Oxford University Press, 2009. 
QUINE, W. V. The Ways of Paradox and Other Essays. Revised edn. Cambridge, MA: Harvard University Press, 1976.

RUSSELL, D. A.; WILSON, N. G. Menander Rhetor. Edited with a Translation \& Commentary. Oxford: Oxford University Press, 1981.

SEAFORD, R. Euripides Bacchae. With an Introduction, Translation and Commentary. Warminster: Aris \& Phillips, 1996.

SORABJI, R. Time, Creation and the Continuum, Theories in Antiquity and the Early Middle Ages. London: Gerald Duckworth \& Co., 1983.

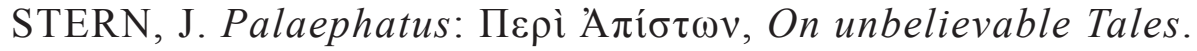
Translation, Introduction, \& Commentary. Wauconda, IL.: BlochazyCarducci Publishers, 1996.

WEST, M. L. Hesiod, Works and Days. Edited with Prolegomena and Commentary. Oxford: Oxford University Press, 1978.

WEST, M. L. Hesiod, Theogony, Works and Days, A New Translation. Oxford: Oxford University Press, 1999.

WINKLER, J. J.; STEPHENS, S. A. Ancient Greek Novels: The Fragments: Introduction, Text, Translation, and Commentary. Princeton: Princeton University Press, 2014.

YUSA, M. Paradox and riddles. In: ELIADE, M. (Ed.-in-chief). The Encyclopedia of Religion, New York: Macmillan Library Reference; London: Simon \& Schuster and Prentice Hall International, 1995. v. XI. p. 194-195.

Recebido em 12 de novembro de 2017. Aprovado em 16 de dezembro de 2017. 